The head measurements were : length, male, 180$190 \mathrm{~mm}$., female, 170-190.2 mm.; breadth, male, 129-143 mm., female, $133-142 \mathrm{~mm}$.; basi-bregmatic height, male, 128-150 mm., female, 129-142 mm.; capacity, male, 1,561 c.c., female, 1,548 e.c. ; cephalic index, male, mean, $74 \cdot 3$, female, $75 \cdot 1$. The skulls show a tendency to vary from a moderate dolichocephaly to mesocephaly, this tendency being more pronounced in the female.

In general character the skull is massive, but without marked prominences, thick, and relatively capacious. In form it is 'beloid'. It is high, especially in the men, and carinated with a pronounced median ridge. The forehead is broad and rounded, the glabella moderately developed. The face is large and low, euryprosopic, and mesognathous to prognathous. The mandibles are robust with a pronounced chin. The dentition is megadont. The teeth are remarkable as showing the first known example of caries, not previously recorded before Neolithic times. The stature is distinctly below medium. The forearm is relatively long. The lower limbs show marked platymeria, and the tibire are platycnemic. As a type, this population is well evolved.

MM. Boule and Vallois have also, as a basis of comparison, made a detailed survey of all the skeletal material of man surviving from the Mesolithic period. This they classify into five types-the Ofnet brachycephal, the dolichocophalic-mesocephals of Téviec, the Ofnet dolichocephals, the Mugem dolichocephals, and the Natufians of Palestine.

On the whole, the authors are inclined to the view that notwithstanding certain clearly marked differences there is a close resemblance between Téviec man and the Chancelade skull of the Upper Palæolithic. It is certainly closer than to Cro-Magnon man. Of the three possibilities that the type is new in western Europe, that it is a cross-breed, or that it is a variation from Chancelade which has been produced in the long interval of time which has elapsed between the occurrence of the two types, the authors incline to the last-named.

\title{
The Electrotor Smoke and Dust Meter
}

\begin{abstract}
A RECENT paper by Dr. S. C. Blacktin (J. Indus. Hygiene and Toxicol.) describes an instrument he has devised for measuring dust suspended in the air. It is of a new type, and in designing it he has attempted to "avoid extraneous mechanisms or electric batteries which mar convenience and portability". The instrument consists of a hand pump of 100 c.c. capacity which draws air through a number of small nozzles, causing it to impinge upon a disk of celluloid or ebonite which, during the impact of the air, is made to revolve by means of a coarsely screwed rod which engages a nut or suitable projection in a hollow piston rod. The revolution of the disk is said to electrify it by rubbing against insulating material. In operation, a clean disk is inserted in the cap and the pump handle is next withdrawn to its greatest extent, and the cap with its disk screwed into position. The pump handle is next pressed inwards, rotating and electrifying the disk and emptying the pump. The ingress port is now held in the dust or smoke dispersion to be determined and the pump handle is withdrawn to its greatest extent
\end{abstract}

with a steady pull. The air or gas entering the ingress holes against the electrified disk is said to deposit its particle content. The records obtained appear to be circular rings upon the record disk, and these are examined in the usual way under a suitable microscope.

In the paper the instrument is illustrated and described, but no data are given on its efficiency of operation. The apparatus is very simple and, provided it fulfils the function it is intended for, should be a useful addition to the methods available.

It is not easy to see how the construction described could be very effective in its operation; for example, it appears that the dust deposit takes place upon the surface of the disk which is being rubbed by rotation and electrified. Mechanically speaking, it cannot be easy to ensure a suitable rubbing pressure between the disk and the surface in contact with it, taking into account the clearances required in the bearings of the screw and such like. However, as stated already, no information is given on its actual use.

J. S. OwENS.

\section{Performance of Noise Meters in Terms of the Primary Standard}

D URING the past few years considerable progress has been made on the intricate subject of noise measurement and many experimental data are now available. A paper on this subject was read by B. G. Churcher and A. J. King to the Institution of Electrical Engineers early this year.

Since loudness is a sensation and not a physical magnitude, its definition and measurement involve subjective considerations such as the manner in which the sound is heard. Until recently these factors were not specified, and so the various types of port. able noise meters in use gave appreciably different indications for a given noise. The British Standard Institution (B.S.I.) has taken an important step in removing difficulties. It has published an authoritative glossary of acoustical terms and definitions (B.S.S. 661) to which most of the workers in Great Britain will conform. Loudness is defined as, "that subjective quality of a sound which, in general, increases regularly with the intensity within the limits of audibility". A natural loudness scale is one such that when the number of units on the scale is doubled the magnitude of the sensation experienced by normal listeners is doubled also. The expression 
"equivalent loudness" has been adopted for the physical intensity level of the reference tone relative to the standard pure tone. The unit of equivalent loudness is the 'phon', which is defined as follows: "The standard tone shall be a plane sinusoidal sound wave train coming from a position directly in front of the observer and having a frequency of 1,000 cycles per sec". It is also stated that the listening must be done by both ears, the standard tone and sound under measurement being heard alternately. If when measured in this way the intensity level is found to be $n$ decibels above the standard tone, the sound is said to have an equivalent loudness of $n$ phons.

Equivalent loudness is defined in terms of the loudness-equality judgment of a hypothetical "normal observer" whose loudness judgment is representative of the average person. A group of persons is therefore selected; the larger and the more representative the group the more closely in all probability the group judgment will approximate to that of the normal observer. Experience shows that good results can be obtained, using mathematical statistical methods, with ten normal observers.
Reproducible noises of physically specified com. position are set up by means of a loud speaker, and their phon values determined in accordance with the definition. The same noises can then be applied to noise meters of any type and the difference between the phon values is the meter error for the type and level of the noise applied.

The measurement of noise is a problem of great and increasing importance in engineering. The authors conclude that the B.S. phon enables a consistent and unifying system of noise measurement to be set up, relevant to the manner in which sounds are normally heard.

The measurement of the frequency, intensity, purity and field distribution of the experimental tones is effected by condenser microphone methods. The analyser has a range of $25-25,000$ cycles per second, is continuously adjustable and is highly sensitive. The microphones are calibrated by means of a Rayleigh disk. An ingenious electromagnetic tone generator is described by means of which harmonic noises containing up to ten components of any relative intensity may be set up.

\section{Academy of Sciences, Vienna}

\section{Annual Meeting}

\begin{abstract}
$A^{T}$ the general meeting of the Academy of A Sciences in Vienna, held on June 1, the following officers were elected: President: Dr. Oswald Redlich, emeritus professor of history in the University of Vienna; General Secretary : Dr. Egon von Schweidler, professor of physics in the University of Vienna; Secretary of the Philosophical and His. torical Section: Dr. Heinrich Ritter von Srbik, professor of history in the University of Vienna.

The following were elected to membership of the Philosophical and Historical Section: Active Members : Dr. Camillo Praschniker, professor of classical archæology, Dr. Rudolf Egger, professor of Roman antiquities, and Dr. Johannes Mewaldt, professor of classical philology, all of the University of Vienna; Corresponding Home Members : Dr. Friedrich Wild, professor of English philology in the University of Vienna, Dr. Franz Martin, director of land administration records in Salzburg, Dr. Alfred von Verdross, professor of international law in the University of Vienna; Honorary Foreign Member: Dr. Edward Schröder, emeritus professo: of German language and literature in the University of Göttingen; Corresponding Foreign Members : Dr. Walter Otto, professor of ancient history in the University of Munich, Dr. Jan Huizinga, professor of history in the University of Leyden, Dr. Friedrich Panzer, professor of German language and literature in the University of Heidelberg, Dr. Theodor Litt, professor of philosophy and pedagogy in the University of Leipzig, Dr. Adolf Grohmann, professor of semitic philology and cultural history of the Orient in the German University of Prague.
\end{abstract}

The following were elected to membership of the Mathematical and Scientific Section: Active Mem- bers: Dr. Karl Terzaghi, professor of hydraulic engineering in the Technische Hochschul in Vienna, Dr. Theodor Pinter, emeritus professor of zoology in the University of Vienna, Dr. Erwin Kruppa, professor of descriptive geometry in the Technische Hochschul in Vienna, Dr. Leopold Adametz, emeritus professor of animal genetics in the Technische Hochschul of Agriculture in Vienna, Dr. Richard Schumann, professor of geodesy and astronomy in the Teshnische Hochschul in Vienna; Corresponding Home Members : Dr. Josef Weninger, professor of anthropology, Dr. Johann Sölch, professor of geography, Dr. Roland Grassberger, professor of hygiene, Dr. Karl Mayrhofer, professor of mathematics, all of the University of Vienna, and Dr. Wilhelm Petras. check, professor of geology, palæontology and stratigraphy in the Montani Hochschul in Leoben; Corresponding Foreign Members: Dr. Otto Grosser, professor of anatomy in the German University of Prague, Dr. Enrico Fermi, professor of physics in the University of Rome, Dr. Ernst Küster, professor of botany in the University of Giessen, Dr. Hermann Nilsson-Ehle, professor of botany in the University of Lund and director of the Plant Breeding Institute in Svalöf.

The following awards were made by the Academy : the Ignaz L. Lieben prize, which this year is awarded for physics, to be divided e qually between Dr. Marietta Blau and Dr. Hertha Wambacher for their work on the photographic action of $\alpha$-rays, protons and neutrons; the Rudolf Wegscheider prize for chemistry to Dr. Otto Brunner for his work on stearins and the vitamins of the eye; the Fritz Pregl prize to Oberst Max Haitinger for his work on fluorescence microscopy. 